\title{
Karakteristik ibu dan pemberian ASI eksklusif dengan kejadian stunting di Kelurahan Padebuolo Kota Gorontalo
}

\author{
Mothers' characteristics and exclusive breastfeeding with stunting incidences \\ in Padebuolo District, Gorontalo
}

\author{
Indra Domili1 ${ }^{*}$, Syafrawati Djamadi Suleman ${ }^{2}$, Fitri Yani Arbie ${ }^{3}$, M. Anas Anasiru \\ Rahma Labatjo 5
}

\author{
${ }^{1}$ Jurusan Gizi Politeknik Kesehatan \\ Kemenkes Gorontalo, Kota Gorontalo, \\ Indonesia. \\ E-mail: indra.domili76@gmail.com \\ 2 Jurusan Gizi Politeknik Kesehatan \\ Kemenkes Gorontalo, Kota Gorontalo, \\ Indonesia. \\ E-mail: yafra.suleman@gmail.com \\ 3 Jurusan Gizi Politeknik Kesehatan \\ Kemenkes Gorontalo, Kota Gorontalo, \\ Indonesia. \\ E-mail: fitri.y.arbie@gmail.com \\ ${ }^{4}$ Jurusan Gizi Politeknik Kesehatan \\ Kemenkes Gorontalo, Kota Gorontalo, \\ Indonesia. \\ E-mail: anasanasiru62@gmail.com \\ 5 Jurusan Gizi Politeknik Kesehatan \\ Kemenkes Gorontalo, Kota Gorontalo, \\ Indonesia. \\ E-mail: rahma.labatjo@gmail.com
}

\section{*Korespondensi:}

Jurusan Gizi, Politeknik Kesehatan Kemenkes Gorontalo, Jalan Taman Pendidikan No. 36, Kota Gorontalo, Gorontalo, Indonesia.

E-mail: indra.domili76@gmail.com

\section{Riwayat Artikel:}

Diterima tanggal 9 Juli 2020; Direvisi tanggal 10 Januari 2021; Disetujui tanggal 30 Januari 2021; Dipublikasi tanggal 26 Mei 2021.

\section{Penerbit:}

Politeknik Kesehatan Aceh Kementerian Kesehatan RI

(C) The Author(s). 2021 Open Access

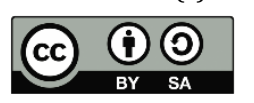
Artikel ini telah dilakukan distribusi berdasarkan atas ketentuan Lisensi Internasional Creative Commons Attribution 4.0

\begin{abstract}
Children who do not get exclusive breastfeeding will be at risk of deficiency of nutrients needed in the growth process. This study aims to analyze the relationship between stunting and exclusive breastfeeding. The research method uses a cross-sectional research design with quantitative research, presented by means of descriptive-analytic with the number of respondents as many as 41 people. Data regarding the child's height was obtained by measuring the child's height using a digital weight scale with an accuracy of 0,1 kg. Data regarding children's age is obtained by birth certificate records or family cards. Mothers' knowledge about exclusive breastfeeding and its giving was obtained using interview techniques. Data analysis using univariate analysis was carried out on each variable resulting from the study in the form of frequency distribution and percentage of each variable. Bivariate analysis to analyze the relationship between variables using Chi-square with $95 \% \mathrm{CI}$. The results showed that knowledge $(p=0,633)$ and education $(p=0,840)$ had no effect on exclusive breastfeeding $(p>0,05)$. Meanwhile, exclusive breastfeeding did not affect the incidence of stunting $(p=0,797)$. In conclusion, education, knowledge and exclusive breastfeeding have no significant correlation with the incidence of stunting in children under five.
\end{abstract}

Keywords: Education, exclusive breastfeeding, knowledge, stunting

\section{Abstrak}

Anak yang tidak mendapatkan ASI eksklusif akan beresiko kekurangan zat gizi yang diperlukan dalam proses pertumbuhan. Penelitian bertujuan untuk menganalisis hubungan kejadian stunting dengan pemberian ASI eksklusif. Metode penelitian menggunakan desain Cross Sectional, dengan jumlah responden sebanyak 41 orang. Data tinggi badan anak didapatkan dengan pengukuran tinggi badan anak menggunakan timbangan berat badan digital dengan ketelitian 0,1 kg. Data mengenai umur anak didapatkan dengan melihat catatan akta kelahiran ataupun kartu keluarga. Data mengenai pengetahuan ibu mengenai ASI eksklusif dan pemberiannya didapatkan dengan menggunakan teknik wawancara. Analisis data dengan menggunakan analisis univariat yang dilakukan terhadap setiap variabel hasil dari penelitian berupa distribusi frekuensi dan persentase dari setiap variabel. Analisis bivariat menggunakan Chi-square dengan CI:95\%. Hasil penelitian menunjukkan bahwa pengetahuan $(p=0,633)$ dan pendidikan $(p=0,840)$ tidak berpengaruh terhadap pemberian ASI eksklusif ( $p>0,05)$. Selanjutnya, pemberian ASI eksklusif juga tidak mempengaruhi kejadian stunting pada balita $(p=0,797)$. Kesimpulan, faktor pendidikan, pengetahuan dan ASI eksklusif tidak berpengaruh terhadap kejadian stunting pada balita di Kelurahan Padebuolo Kota Gorontalo.

Kata Kunci: ASI eksklusif, pengetahuan, pendidikan stunting 


\section{Pendahuluan}

Stunting merupakan gangguan gizi kronis yang menyebabkan pertumbuhan tinggi anak tidak sesuai dengan bertambahnya umur balita (Sariy et al., 2018). Stunting dikenal dengan istilah pendek dan sangat pendek. Angka stunting di Indonesia mengalami peningkatan secara signifikan (Arbie \& Labatjo, 2019).

Angka prevalensi pendek secara nasional pada tahun 2018 menurut laporan Riskesdas 2018 adalah 30,8\%. Persentase anak balita yang sangat pendek dan pendek di Provinsi Gorontalo masing-masing sebanyak $12,7 \%$ dan 19,8\% (Balitbangkes, 2018). Berdasarkan data yang diperoleh dari Tim Nasional Percepatan Penanggulangan Kemiskinan tahun 2017, menyatakan bahwa prevalensi, jumlah balita stunting di daerah Kabupaten/Kota Gorontalo tercatat jumlah balita stunting sebanyak 14.824 Jiwa dengan prevalensi stunting sebanyak 42,6\% Jiwa (Kalla, 2017).

Beberapa faktor diketahui sebagai faktor resiko terjadinya stunting. Penyakit infeksi, inisiasi menyusui dini, pemberian ASI esklusif dan riwayat berat badan lahir rendah merupakan faktor-faktor yang mempengaruhi terjadinya stunting (Sariy et al., 2018; AL Rahmad \& Miko, 2016). Selain itu, Riwayat pemberian ASI eksklusif dan waktu pemberian makanan pendamping ASI yang tepat, dapat mencegah stunting (Sariy et al., 2018).

Pengetahuan dapat berpengaruh pada pemberian ASI eksklusif. Ibu yang mengerti dan paham akan manfaat ASI eksklusif terhadap pertumbuhan anak, cenderung akan memberikan ASI secara eksklusif kepada anaknya. Sebaliknya, jika pengetahuan ibu mengenai dampak positif ASI eksklusif terhadap pertumbuhan dan perkembangan anak tidak adekuat, maka mereka kemungkinan besar tidak akan menyusui secara eksklusif (Rahayu et al., 2019). Pengetahuan tidak lepas dengan tingkat pendidikan. Ibu dengan tingkat pendidikan tinggi akan lebih mudah menyerap informasi. Informasi mengenai manfaat ASI eksklusif dapat dipahami dengan lebih maksimal. Sehingga faktor tingkat pendidikan dapat memberikan pengaruh positif terhadap pemberian ASI eksklusif dan perbaikan status gizi anak (Rohmatun, 2014).

Faktor predisposisi lainnya yang dapat berpengaruh terhadap pemberian ASI eksklusif dan status gizi balita adalah umur ibu. Umur ibu berkontribusi terhadap banyaknya pengalaman dalam hal pengasuhan anak. Ibu dengan umur yang matang, mempunyai pengalaman yang cukup. Sehingga pengalaman yang telah didapatkan dapat diaplikasikan dalam pengasuhan anak, khususnya pemberian ASI eksklusif (Rahayu et al., 2019).

Ibu bekerja cenderung untuk tidak menyusui secara eksklusif. Hal ini disebabkan kurangnya waktu ibu dalam mengasuh anak. Waktu ibu sebagian besar dihabiskan untuk bekerja. Dampaknya, sebagian besar ibu bekerja memilih untuk memberikan susu formula. Perilaku ini menyebabkan adanya masalah gizi seperti stunting pada anak (Okawary, 2015).

Kementerian Kesehatan RI (2017), menyatakan bahwa secara nasional cakupan pemberian ASI eksklusif pada bayi usia kurang dari enam bulan sebesar 54,0\%. Hal ini berarti, cakupan pemberian ASI eksklusif secara nasional pada bayi usia kurang dari enam bulan telah mencapai target dengan mengacu pada renstra tahun 2016 yang sebesar $42 \%$. Secara provinsi, cakupan pemberian ASI Eksklusif pada bayi umur 0-5 bulan di Provinsi Gorontalo tahun 2016 berkisar antara 32,3\%. Dari 34 provinsi di Indonesia, Provinsi Gorontalo termasuk belum mencapai target. Hal ini tentunya sangat memprihatinkan. Oleh karena, anak yang tidak mendapatkan ASI eksklusif akan berisiko lebih tinggi untuk kekurangan zat gizi yang diperlukan dalam proses pertumbuhan. Gangguan pertumbuhan tersebut akan menyebabkan terjadinya stunting pada anak (Al-Anshori \& Nuryanto, 2013).

Berdasarkan data yang diperoleh dari Dinas

Kesehatan Kota Gorontalo tahun 2017, menyebutkan bahwa jumlah bayi yang diberi ASI eksklusif usia 0-6 bulan di Kota Timur sebanyak 45,6 \% (Dinkes Gorontalo, 2017). Masalah stunting dapat dicegah dengan beberapa hal yaitu memberikan ASI eksklusif, memberikan makanan yang bergizi sesuai kebutuhan tubuh dan memantau tumbuh kembang anak secara teratur (Millenium Challenge Account Indonesia, 2015). Berdasarkan kajian pendahuluan serta tingginya masalah stunting di Kota Gorontalo, maka tujuan dalam penelitian ini adalah untuk menganalisis hubungan antara pemberian ASI eksklusif ditinjau dari karakteristik ibu yang mencakup pendidikan dan pengetahuan dengan kejadian stunting di Kelurahan Padebuolo Kota Gorontalo. 


\section{Metode}

Penelitian ini merupakan penelitian deskriptif yang mengeksplor variabel pengetahuan dan perilaku ibu terhadap ASI eksklusif pada balita stunting. Desain penelitian yang digunakan adalah cross sectional study. Penelitian dilakukan di Kelurahan Padebuolo Kota Gorontalo tahun 2019.

Sampel penelitian sebanyak 41 ditentukan dengan menggunakan formula sebagai berikut.

$n=\frac{Z^{2} 1-\alpha / 2(P-(1-P))}{d^{2}}$

Keterangan:

$\begin{aligned} \mathrm{n} & =\text { Jumlah sampel } \\ \mathrm{Z}^{2}{ }_{1-\alpha / 2}= & \mathrm{Z} \text {-score pada 1- } \alpha / 2 \text { tingkat } \\ & \text { kepercayaan }(1,645) \\ \mathrm{P} & =\text { Estimasi proporsi }(50 \%) \\ \mathrm{d}^{2}= & \text { Presisi yang ditetapkan }(10 \%)\end{aligned}$

Data dan variabel tinggi badan anak didapatkan dengan pengukuran tinggi badan anak menggunakan timbangan berat badan digital dengan ketelitian 0,1 kg. Data mengenai umur anak didapatkan dengan melihat catatan akta kelahiran ataupun kartu keluarga. Kategori stunting ditentukan dengan menggunakan klasifikasi menurut Keputusan Menteri Kesehatan Peraturan Menteri Kesehatan Republik Indonesia Nomor 2 Tahun 2020. Data mengenai pengetahuan ibu mengenai ASI eksklusif dan pemberiannya didapatkan dengan menggunakan teknik wawancara. Data tiap variabel diolah menggunakan kategori.

Data mengenai umur dikategorikan dalam satuan tahun. Pendidikan dikategorikan menjadi pendidikan dasar, pendidikan menengah dan pendidikan tinggi. Jenis pekerjaan ibu dibagi menjadi ibu rumah tangga, wiraswasta dan karyawan. Sedangkan data mengenai tingkat pengetahuan dibedakan menjadi baik dan cukup. Pemberian ASI dikategorikan eksklusif dan tidak eksklusif. Data stunting diklasifikasikan menjadi stunting dan tidak stunting.

Penelitian telah mendapat persetujuan etik atau Ecthical clearence yang diperoleh dari Komisi Etik Poltekkes Kemenkes Gorontalo dengan nomor LB.01.01/KEPK/20/2020.

Analisis data dengan menggunakan analisis univariat yang dilakukan terhadap setiap variabel hasil dari penelitian berupa distribusi frekuensi dan persentase dari setiap variabel.
Analisis bivariat untuk menganalisis hubungan antar variabel menggunakan Chi-square dengan CI 95\% dan alfa 0,05.

\section{Hasil dan Pembahasan}

\section{Karakteristik Responden}

Karakterisitik responden dalam penelitian ini yang diukur terdiri dari umur, pendidikan dan jenis pekerjaan. Data mengenai karakterisitik responden dapat dilihat pada tabel 1 berikut.

Tabel 1. Karakteristik responden penelitian

\begin{tabular}{llcc}
\hline Karakteristik & Kategori & $\mathrm{n}$ & $\%$ \\
\hline Umur & $17-30$ & 17 & 41,5 \\
Pendidikan & $31-43$ & 24 & 58,5 \\
& Dasar & 6 & 14,6 \\
& Menengah & 30 & 73,2 \\
\multirow{5}{*}{ Jenis pekerjaan } & Tinggi & 5 & 12,2 \\
& IRT & 37 & 90,2 \\
& Wiraswasta & 3 & 7,3 \\
& Karyawan & 1 & 2,5 \\
\hline
\end{tabular}

Gambaran umum data distribusi mengenai umur responden/ibu balita yang memiliki anak balita dengan kategori usia 0-59 bulan di Kelurahan Padebuolo, berdasarkan tabel 1, dapat dilihat bahwa ibu balita yang dijadikan sebagai responden sebagian besar memiliki umur 31-43 tahun $(58,5 \%)$ dan sebagian kecil responden/ibu balita memiliki umur $17-30$ tahun $(41,5 \%)$. Usia dapat mempengaruhi motivasi dan aktivitas seorang ibu dalam menyusui. Usia antara 20 - 35 tahun merupakan masa reproduksi sehat. Oleh karena itu, secara fisik organ reproduksi dan kondisi psikologis ibu telah siap dalam menerima kehadiran seorang bayi. Pada umumnya ibu yang usianya 20 - 35 tahun memiliki kemampuan laktasi yang lebih baik dibandingkan dengan ibu yang usianya lebih dari 35 tahun, sehingga pengeluaran ASI-nya lebih sedikit dibandingkan dengan yang berusia reproduktif. Adapun ibu yang berada pada usia kurang dari 20 tahun secara psikis umumnya belum siap untuk menjadi ibu, sehingga bisa menjadi beban psikologis yang akan menyebabkan depresi dan produksi ASI yang rendah (Hanifah et al., 2017).

Berdasarkan karakteristik Pendidikan responden (tabel 1), tergambarkan bahwa tingkat pendidikan ibu balita yang dijadikan sebagai responden sebagian besar tamat SMA/SMK $(73,2 \%)$ dan hanya sebagian kecil tamat D1/D3/Perguruan Tinggi (12,2\%). 
Pendidikan orang tua atau keluarga terutama ibu bayi merupakan salah satu faktor yang penting dalam mendukung keberhasilan pemberian ASI eksklusif pada bayi. Secara umum, ibu dengan pendidikan sedang sampai tinggi dapat menerima hal-hal baru dalam memelihara kesehatan khususnya tentang ASI eksklusif. Mereka akan cenderung terdorong untuk ingin tahu dan mencari pengalaman baru, sehingga informasi yang didapat akan menjadi pengetahuan yang nantinya akan diterapkan pada kehidupannya sehari-hari. Adapun ibu dengan tingkat pendidikan yang rendah akan menyebabkan sulitnya ibu dalam menerima arahan mengenai pemberian ASI eksklusif (Hartini, 2014).

Selanjutnya, karakteristik berdasarkan jenis pekerjaan bahwa ibu balita yang dijadikan sebagai responden sebagian besar adalah ibu rumah tangga $(90,2 \%)$ dan hanya $2,5 \%$ sebagai karyawan. Salah satu faktor yang dapat mempengaruhi keberhasilan dan kegagalan pemberian ASI eksklusif salah satunya adalah pada ibu yang memiliki pekerjaan. Para ibu yang beralih ke susu formula disebabkan karena terhentinya pemberian ASI eksklusif. terutama ibu yang bekerja di daerah perkotaan. Hal ini terjadi karena ibu yang bekerja mempunyai keterbatasan untuk menyusui bayinya secara langsung. Apabila ibu bekerja mempunyai pengetahuan yang cukup mengenai manfaat, cara penyimpanan, termasuk juga pemberian ASI eksklusif maka dapat meningkatkan pemberian ASI eksklusif (Rahmad et al., 2013). Adapun dengan ibu yang tidak bekerja, mereka pada umumnya dapat memberikan ASI kapanpun pada bayinya dengan frekuensi yang lebih sering disebabkan karena ibu yang tidak bekerja memiliki waktu yang lebih banyak bersama anaknya daripada ibu yang bekerja (Okawary, 2015).

\section{Pengaruh Pendidikan dan Pengetahuan dengan Pemberian ASI}

Hasil penelitian sebagaimana yang disajikan pada tabel 2, menunjukkan bahwa secara proporsi sebesar $80,0 \%$ ibu yang berpendidikan tinggi tidak memberikan ASI eksklusif kepada bayi mereka. Begitu juga berdasarkan tngkat pengetahuan, sebesar $83,3 \%$ ibu yang berpengetahuan ternyata tidak melakukan pemberian ASI secara eksklusif kepada bayi mereka di Kelurahan Padebuolo Kota Gorontalo.

Berdasarkan karakteristik Pendidikan ibu, Hasil uji Chi-square menunjukkan bahwa tingkat pendidikan ibu tidak berpengaruh terhadap pemberian ASI eksklusif $(p=0,848)$. Rendahnya perilaku responden dalam memberikan ASI eksklusif tidak hanya dipengaruhi oleh tingkat pendidikan responden, akan tetapi kemungkinan dapat dipengaruhi oleh beberapa faktor lain seperti kurangnya motivasi ibu dalam memberikan ASI eksklusif pada bayinya, kurangnya dukungan suami/keluarga serta kurangnya dukungan sosial budaya setempat (Listyaningrum \& Vidayanti, 2016). Perilaku seseorang dipengaruhi oleh faktor predisposisi, faktor pendukung dan faktor pendorong. Faktor predisposisi antara lain, pengetahuan, pendidikan, pekerjaan, usia, paritas, motivasi dan sosial ekonomi. Faktor pendukung yaitu, sarana atau fasilitas kesehatan dan jarak ke pelayanan kesehatan sedangkan faktor pendorong antara lain dukungan suami/keluarga, dukungan sosial, perilaku/ perilaku petugas kesehatan dan keterampilan petugas Kesehatan (Septiani et al., 2017).

Table 2. Pengaruh pengetahuan dan Pendidikan ibu dengan pemberian ASI

\begin{tabular}{|c|c|c|c|c|c|c|c|c|}
\hline \multirow{3}{*}{$\begin{array}{l}\text { Pendidikan Ibu dan } \\
\text { Pengetahuan Ibu }\end{array}$} & \multicolumn{4}{|c|}{ Pemberian ASI } & \multirow{2}{*}{\multicolumn{2}{|c|}{ Total }} & \multirow{3}{*}{ Nilai p } & \multirow{3}{*}{$\begin{array}{c}\text { OR } \\
(95 \%: \mathrm{CI})\end{array}$} \\
\hline & \multicolumn{2}{|c|}{ Tidak Eksklusif } & \multicolumn{2}{|c|}{ Eksklusif } & & & & \\
\hline & $\mathrm{n}$ & $\%$ & $\mathrm{n}$ & $\%$ & $\mathrm{n}$ & $\%$ & & \\
\hline \multicolumn{9}{|l|}{ Tingkat Pendidikan } \\
\hline Dasar & 4 & 66,7 & 2 & 33,3 & 6 & 100,0 & 0,848 & $0,6(0,1-4,1)$ \\
\hline Menengah & 23 & 76,7 & 7 & 23,3 & 30 & 100,0 & 0,869 & $0,8(0,1-8,6)$ \\
\hline Tinggi & 4 & 80,0 & 1 & 20,0 & 5 & 100,0 & & \\
\hline \multicolumn{9}{|l|}{ Pengetahuan } \\
\hline Cukup & 26 & 74,3 & 9 & 25,7 & 35 & 100,0 & 0,633 & $0,6(0,1-5,6)$ \\
\hline Baik & 5 & 83,3 & 1 & 16,7 & 6 & 100,0 & & \\
\hline Jumlah & 31 & 75,6 & 10 & 24,4 & 41 & 100,0 & & \\
\hline
\end{tabular}

Pengetahuan merupakan domain yang sangat penting dalam terbentuknya perilaku seseorang. Selain itu, pengetahuan merupakan pengindraan manusia atau hasil tahu seseorang 
terhadap objek melalui indera yang dimilikinya (Notoatmodjo, 2011). Dalam penelitian ini, pengetahuan responden/ibu balita sebagian besar memilliki pengetahuan cukup dengan, yang berarti bahwa responden/ibu balita dalam penelitian ini berpengetahuan yang cukup baik dan mampu menerima informasi/edukasi tentang pemberian ASI eksklusif. Hasil uji statistik (tabel 2) pada taraf signifikansi 0,05 diperoleh nilai $p=0,633$ yang menyatakan bahwa pengetahuan responden tidak berhubungan dengan pemberian ASI eksklusif pada bayi di Kelurahan Padebuolo Kota Gorontalo ( $p>0,05)$.

Pengetahuan ibu tentang ASI eksklusif dapat mempengaruhi ibu dalam memberikan ASI eksklusif. Semakin baik pengetahuan ibu tentang manfaat ASI eksklusif, maka seorang ibu akan semakin termotivasi untuk memberikan ASI eksklusif pada anaknya. Begitu pun sebaliknya, semakin rendah pengetahuan ibu tentang manfaat ASI eksklusif, maka semakin sedikit juga motivasi ibu dalam memberikan ASI eksklusif(Nurkhayati, 2014). Oleh karenanya, pengetahuan mengenai ASI merupakan salah satu faktor yang berkaitan dengan perilaku pemberian ASI (Rahayu et al., 2019).
Namun demikian, pengetahuan bukan merupakan faktor absolut yang dapat mempengaruhi pemberian ASI secara eksklusif. Hasil penelitian oleh Mabud et.al., menyebutkan bahwa tingkat pengetahuan tidak berhubungan dengan pemberian ASI eksklusif (Mabud et al., 2014). Faktor lainnya seperti marketing susu formula, perubahan pola piker dan gaya hidup merupakan faktor yang dapat berpengaruh terhadap pemberian ASI eksklusif (Rahayu et al., 2019). Keterpaparan ibu dengan berbagai media informasi yang menyebarkan informasi mengenai manfaat ASI eksklusif, tidak berpengaruh signifikan terhadap perilaku ibu dalam memberikan ASI secara eksklusif (Pitaloka et al., 2018).

\section{Pengaruh Pemberian ASI Eksklusif dengan Kejadian Stunting}

Telah diketahui bahwa pemberian ASI eksklusif masih rendah di Kelurahan Padebuolo Kota Gorontalo, yaitu sebesar 24,4\%. Sedangkan prevalensi stunting pada balita yaitu sebesar $36,6 \%$. Tabel 2, menyajikan informasi terkait dengan pengaruh pemberian ASI eksklusif dengan kejadian stunting pada balita di Kelurahan Padebuolo Kota Gorontalo.

Table 2. Pengaruh pengetahuan dan Pendidikan ibu dengan pemberian ASI

\begin{tabular}{|c|c|c|c|c|c|c|c|c|}
\hline \multirow{3}{*}{$\begin{array}{l}\text { Pemberian ASI } \\
\text { Eksklusif }\end{array}$} & \multicolumn{4}{|c|}{ Kejadian Stunting } & \multirow{2}{*}{\multicolumn{2}{|c|}{ Total }} & \multirow{3}{*}{ Nilai p } & \multirow{3}{*}{$\begin{array}{c}\text { OR } \\
\text { (95\%: CI) }\end{array}$} \\
\hline & \multicolumn{2}{|c|}{ Stunting } & \multicolumn{2}{|c|}{ Normal } & & & & \\
\hline & $\mathrm{n}$ & $\%$ & $\mathrm{n}$ & $\%$ & $\mathrm{n}$ & $\%$ & & \\
\hline Tidak Eksklusif & 11 & 35,5 & 20 & 64,5 & 31 & 100,0 & 0,797 & $0,8(0,2-3,6)$ \\
\hline Eksklusif & 4 & 40,0 & 6 & 60,0 & 10 & 100,0 & & \\
\hline Jumlah & 15 & 36,6 & 26 & 63,4 & 41 & 100,0 & & \\
\hline
\end{tabular}

Hasil uji statistic sebagaimana telah disajikan pada tabel 2, diperoleh nilai $\mathrm{p}=0,797 \mathrm{p}$ $>0,05$ ) yang menyimpulkan bahwa pemberian ASI eksklusif tidak berpengaruh terhadap kejadian stunting pada balita di Kelurahan Padebuolo Kota Gorontalo. Hal ini berarti bahwa, masalah stunting tidak hanya dipengaruhi oleh faktor pemberian ASI eksklusif saja. Banyak faktor lain yang berperan dalam terjadinya masalah stunting pada balita. Riwayat pemberian ASI eksklusif bukan merupakan satu-satunya faktor penyebab kejadian stunting pada Usia 2459 bulan, akan tetapi adanya faktor resiko lainnya yang mendukung terjadinya masalah stunting pada balita (Saputri et al., 2018).

Hasil penelitian ini berbanding terbalik dengan hasil penelitian yang dilakukan oleh Indrawati (2016) tentang hubungan pemberian ASI eksklusif dengan kejadian stunting pada anak usia 2-3 tahun, yang menyatakan bahwa adanya hubungan antara pemberian ASI eksklusif terhadap kejadian stunting pada anak balita. ASI adalah asupan zat gizi yang sesuai dengan kebutuhan bayi dalam menunjang proses pertumbuhan dan perkembangan bayi tersebut. Bayi yang tidak mendapatkan ASI dengan cukup akan memiliki asupan zat gizi yang kurang baik sehingga dapat menyebabkan terjadinya masalah stunting.

Salah satu manfaat ASI eksklusif adalah untuk mendukung proses pertumbuhan bayi terutama dalam menunjang proses pertambahan tinggi badan bayi tersebut. Hal ini disebabkan adanya kandungan kalsium pada ASI yang lebih banyak dan lebih mudah diserap tubuh dengan 
baik dibandingkan dengan kalsium yang terdapat pada susu pengganti ASI atau susu formula, sehingga bayi yang diberikan ASI eksklusif akan lebih cenderung memiliki tinggi badan yang lebih dan sesuai dengan kurva pertumbuhan dibandingkan dengan bayi yang hanya diberikan susu formula (Indrawati, 2016).

Stunting adalah masalah gizi utama yang akan berdampak pada kehidupan sosial dan ekonomi dalam masyarakat. Selain itu, stunting juga dapat berpengaruh pada anak balita dalam jangka waktu yang panjang seperti mengganggu kesehatan, pendidikan serta produktifitasnya di kemudian hari. Anak balita stunting cenderung akan sulit mencapai potensi pertumbuhan dan perkembangan yang optimal baik secara fisik maupun psikomotorik (Aridiyah et al., 2015).

Hasil penelitian yang dilakukan oleh Picauly \& Toy (2013) menyatakan bahwa adanya indikasi stunting berpengaruh terhadap prestasi belajar anak. Siswa yang stunting lebih banyak memiliki prestasi belajar yang kurang sedangkan siswa yang tidak mengalami stunting lebih banyak memiliki prestasi belajar yang baik.

Masalah stunting yang terjadi pada balita menurut Kusuma \& Nuryanto (2013) disebabkan oleh banyak faktor diantaranya adalah panjang badan lahir, status ekonomi keluarga, tingkat pendidikan dan tinggi badan orang tua. Panjang badan lahir pendek merupakan salah satu faktor risiko stunting pada balita. Panjang badan lahir pendek bisa disebabkan oleh faktor genetik yaitu tinggi badan orang tua yang pendek, maupun karena kurangnya pemenuhan zat gizi pada masa kehamilan.

Panjang badan lahir pendek pada anak menunjukkan kurangnya asupan zat gizi ibu selama masa kehamilan, sehingga pertumbuhan janin tidak optimal dan akhirnya mengakibatkan bayi lahir dengan panjang badan lahir pendek. Panjang badan lahir berkaitan erat dengan tinggi badan orang tua. Ibu dengan tinggi badan pendek lebih berpeluang utntuk melahirkan anak yang pendek (Miko \& Al-Rahmad, 2017). Selain panjang badan lahir dan tinggi badan orang tua, status ekonomi keluarga dan pendidikan orang tua juga merupakan faktor risiko kejadian stunting pada balita (Kusuma \& Nuryanto, 2013).

Status ekonomi keluarga dipengaruhi oleh beberapa faktor, antara lain pekerjaan orang tua, tingkat pendidikan orang tua dan jumlah anggota keluarga. Status ekonomi keluarga akan mempengaruhi kemampuan pemenuhan gizi keluarga maupun kemampuan mendapatkan layanan kesehatan (WHO, 2018). Anak pada keluarga dengan tingkat ekonomi rendah lebih berisiko mengalami stunting karena kemampuan pemenuhan gizi yang rendah, meningkatkan risiko terjadinya malnutrisi. Tingkat pendidikan orang tua yang rendah juga disinyalir meningkatkan risiko malnutrisi pada anak. Tingkat pendidikan orang tua akan berpengaruh terhadap pengetahuan orang tua terkait gizi dan pola pengasuhan anak, dimana pola asuh yang tidak tepat akan meningkatkan risiko kejadian stunting (Kusuma \& Nuryanto, 2013).

\section{Kesimpulan}

Faktor pendidikan dan pengetahuan ibu tidak memiliki pengaruh terhadap pemberian ASI eksklusif. Demikian pula dengan faktor pemberian ASI eksklusif yang tidak berpengaruh secara signifikan terhadap kejadian stunting di Kelurahan Padebuolo Kota Gorontalo.

Tingkat pengetahuan ibu balita mengenai pemberian ASI eksklusif sudah cukup baik, namun, perilaku ibu balita dalam memberikan ASI eksklusif masih rendah. Untuk itu diperlukan kerjasama multi stake-holders dalam meningkatkan promosi ASI eksklusif dalam rangka pencegahan stunting.

\section{Daftar Rujukan}

Al-Anshori, H., \& Nuryanto, N. (2013). Faktor risiko kejadian stunting pada anak usia 1224 bulan (Studi di Kecamatan Semarang Timur). Journal of Nutrition College, 2(4), 675-681. https://doi.org/10.14710/jnc.v2i4.3830

AL Rahmad, A. H., \& Miko, A. (2016). Kajian stunting pada anak balita berdasarkan pola asuh dan pendapatan keluarga di Kota Banda Aceh. Kesmas Indonesia, 8(02), 58-77.

Arbie, F. Y., \& Labatjo, R. (2019). Examining the nutrition levels and stunting problem in Indonesian children. AcTion: Aceh Nutrition Journal, 4(2), 89-98. https://doi.org/http://dx.doi.org/10.3086 7/action.v4i2.126

Aridiyah, F. O., Rohmawati, N., \& Ririanty, M. (2015). Faktor-faktor yang mempengaruhi 
kejadian stunting pada anak balita di wilayah pedesaan dan perkotaan. Pustaka Kesehatan, 3(1), 163-170.

Balitbangkes. (2018). Laporan Nasional Riskesdas 2018. In Jakarta: Badan Penelitian dan Pengembangan Kesehatan.

Dinkes Gorontalo. (2017). Hasil Pelaksanaan Pemantauan Status Gizi (PSG) Gorontalo. In Bidang Gizi Masyarakat, Dinas Kesehatan Provinsi Gorontalo.

Hanifah, S. A., Astuti, S., \& Susanti, A. I. (2017). Gambaran karakteristik ibu menyusui tidak memberikan ASI eksklusif di Desa Cikeruh Kecamatan Jatinangor Kabupaten Sumedang Tahun 2015. Jurnal Sistem Kesehatan, 3(1), 38-43. https://doi.org/https://doi.org/10.24198/ jsk.v3i1.13960

Hartini, S. (2014). Hubungan tingkat pendidikan ibu dengan keberhasilan ASI eksklusif pada bayi Umur 6-12 Bulan di Puskesmas Kasihan II Yogyakarta. In Program Studi Ilmu Keperawatan. Sekolah Tinggi Ilmu Kesehatan 'Aisyiyah Yogyakarta.

Indrawati, S. (2016). Hubungan pemberian ASI eksklusif dengan kejadian stunting pada anak usia 2-3 tahun di Desa Karangrejek Wonosari Gunungkidul. In Prodi Ilmu Keperawatan. Universitas 'Aisyiyah Yogyakarta.

Kalla, M. J. (2017). 100 Kabupaten/Kota Prioritas untuk Intervensi Anak Kerdil (Stunting) (1st ed., pp. 5-7). Sekretariat Wakil Presiden Republik Indonesia.

Kementerian Kesehatan RI. (2017). Profil Kesehatan Indonesia 2016.

Kusuma, K. E., \& Nuryanto. (2013). Faktor risiko kejadian stunting pada anak usia 2-3 tahun (Studi di Kecamatan Semarang Timur). Journal of Nutrition College, 2(4), 523-530. https://doi.org/https://doi.org/10.14710/ jnc.v2i4.3735

Listyaningrum, T. U., \& Vidayanti, V. (2016). Tingkat pengetahuan dan motivasi ibu berhubungan dengan pemberian ASI eksklusif pada ibu bekerja. Jurnal Ners Dan Kebidanan Indonesia, 4(2), 55-62. https://doi.org/http://dx.doi.org/10.2192 7/jnki.2016.4(2).55-62

Mabud, N. H., Mandang, J., \& Mamuaya, T. (2014). Hubungan pengetahuan, pendidikan, paritas dengan pemberian ASI eksklusif di Puskesmas Bahu Kecamatan Malalayang Kota Manado.
Jurnal Ilmiah Bidan, 2(2), 51-56. https://doi.org/https://doi.org/10.47718/ jib.v2i2.316

Miko, A., \& Al-Rahmad, A. H. (2017). Hubungan berat dan tinggi badan orang tua dengan status gizi balita di Kabupaten Aceh Besar. Gizi Indonesia, 40(1), 21-34. https://doi.org/https://doi.org/10.36457/ gizindo.v40i1.222

Millenium Challenge Account Indonesia. (2015). Backgrounder: Stunting dan masa depan indonesia. www.mca-indonesia.go.id

Notoatmodjo, S. (2011). Kesehatan Masyarakat Ilmu dan Seni (Revisi). Rineka Cipta.

Nurkhayati, A. (2014). Hubungan antara pengetahuan ibu tentang ASI eksklusif dengan motivasi pemberian ASI eksklusif. Universitas Muhammadiyah Surakarta.

Okawary, O. (2015). Hubungan status pekerjaan ibu dengan pemberian ASI eksklusif di Wilayah Kerja Puskesmas Seyegan Sleman Yogyakarta. In Program Studi Ilmu Keperawatan. Sekolah Tinggi Ilmu Kesehatan 'Aisyiyah Yogyakarta.

Picauly, I., \& Toy, S. M. (2013). Analisis determinan dan pengaruh stunting terhadap prestasi belajar anak sekolah di Kupang dan Sumba Timur, NTT. Jurnal Gizi Dan Pangan, 8(1), 55-62. https://doi.org/https://doi.org/10.25182/ jgp.2013.8.1.55-62

Pitaloka, D. A., Abrory, R., \& Pramita, A. D. (2018). Hubungan antara pengetahuan dan pendidikan ibu dengan pemberian ASI eksklusif di Desa Kedungrejo Kecamatan Waru Kabupaten Sidoarjo. Amerta Nutrition, 2(3), 265. https://doi.org/10.20473/amnt.v2i3.2018. 265-270

Rahayu, S., Djuhaeni, H., Nugraha, G. I., \& Mulyo, G. E. (2019). Hubungan pengetahuan, sikap, perilaku dan karakteristik ibu tentang ASI eksklusif terhadap status gizi bayi. AcTion: Aceh Nutrition Journal, 4(1), 28-35. https://doi.org/http://dx.doi.org/10.3086 7/action.v4i1.149

Rahmad, A. H. Al, Miko, A., \& Hadi, A. (2013). Kajian stunting pada anak balita ditinjau dari pemberian ASI eksklusif, MP-ASI, status imunisasi dan karakteristik keluarga di Kota Banda Aceh. J Kesehatan Ilmiah Nasuwakes, 6(2), 169-184.

Rohmatun, N. Y. (2014). Hubungan tingkat pendidikan ibu dan pemberian ASI eksklusif 
dengan kejadian stunting pada balita di Desa Sidowarno Kecamatan Wonosari Kabupaten Klaten. In Program Studi Gizi, Fakultas Ilmu Kesehatan. Universitas Muhammadiyah Surakarta.

Saputri, B. E., Malonda, N. S. H., \& Amisi, M. D. (2018). Hubungan antara riwayat pemberian ASI dengan status gizi pada anak usia 24-59 bulan di wilayah kerja Puskesmas Pusomaen Kabupaten Minahasa Tenggara. Kesmas, 7(4), 56-72.

Sariy, R. B., Simanjuntak, B. Y., \& Suryani, D. (2018). Pemberian MP-ASI dini dengan status gizi (PB/U) usia 4-7 bulan di Kecamatan Ratu Samban Kota Bengkulu. AcTion: Aceh Nutrition Journal, $3(2)$, 103-109. https://doi.org/http://dx.doi.org/10.3086 7/action.v3i2.95

Septiani, H. U., Budi, A., \& Karbito, K. (2017). Faktor-faktor yang berhubungan dengan pemberian ASI eksklusif oleh ibu menyusui yang bekerja sebagai tenaga kesehatan. Aisyah: Jurnal Ilmu Kesehatan, 2(2), 217373. https://doi.org/https://doi.org/10.30604/ jika.v2i2.62

WHO. (2018). Reducing stunting in children: equity considerations for achieving the global nutrition targets 2025. In Department of Nutrition for Health and Development. Department of Nutrition for Health and Development. World Health Organization. 